\section{Fluoxetine accumulation and metabolism as exposure biomarker to better understand biological effects in gastropods}

\author{
M. Gust, ${ }^{1}$ C. Cren-Olivé, ${ }^{2}$ A. Bulete, ${ }^{2}$ \\ T. Buronfosse, ${ }^{3}$ J. Garric ${ }^{1}$
}

'IRSTEA, UR MALY, Laboratoire d'écotoxicologie, Villeurbanne; ${ }^{2}$ Service Central

d'Analyse du CNRS - USR59,

Villeurbanne; ${ }^{3}$ VetAgroSup. Ecole

Nationale Vétérinaire de Lyon, Marcy

l’Etoile, France

\section{Introduction}

Fluoxetine is a widely used antidepressant frequently found in wastewater treatment plant effluent and in aquatic ecosystems at concentrations below $\mu \mathrm{g} / \mathrm{L} .{ }^{1}$ Numerous studies have explored the sensitivity of invertebrates to waterborne fluoxetine showing marked differences of sensitivity. In a previous study, the New-Zealand mudsnail, Potamopyrgus antipodarum, and the European valve snail, Valvata piscinalis, were exposed to waterborne fluoxetine $(3.7-100 \mu \mathrm{g} / \mathrm{L})$ during 42 days. While effects were observed on the mudsnail reproduction and F1, the valve snail was not affected. Several assumptions were proposed to explain these results including dissimilar metabolic capacities or bioavailability of fluoxetine for the snails. ${ }^{2}$ Indeed, recently, fluoxetine was measured in tissues of mussels Eliptio complanata exposed downstream of a municipal wastewater, assorted with reproductive effects under laboratory experiments. ${ }^{3}$ Both fluoxetine and norfluoxetine (the active metabolite) have been measured in tissues of fishes sampled or caged in streams downstream of urban and industrialized effluent discharges. ${ }^{4-7}$ Thus the aim of this study was to asses if differential sensitivity of gastropods snails to fluoxetine could be explained by its bioaccumulation and metabolism into norfluoxetine.

\section{Materials and Methods}

$P$. antipodarum and $V$. piscinalis were exposed in the same beakers to fluoxetine as previously described and concentrations were chosen in accordance with the biological effects observed in these species. ${ }^{2}$ However, due to lack of abundance of $V$. piscinalis in our culture, exposure of the both species was not rigorously similar. The nominal exposure concentrations were 11,33 and $100 \mu \mathrm{g} / \mathrm{L}$ for
P. antipodarum plus a control, and $33,100 \mu \mathrm{g} / \mathrm{L}$ plus a control for $V$. piscinalis. Six replicates per concentration were prepared and exposed for 7 (V. piscinalis) and 14 days (P. antipodarum). Organisms were fed ad libitum. Adult snails were used at the start of the experiment. On days 7 and 14, 3 P. antipodarum were collected per condition for fluoxetine and norfluoxetine analysis and $3 \mathrm{~V}$. piscinalis on day 7 . Due to the lipophilic nature of fluoxetine,, 8 triacylglycerol (TG) content of snails was measured, ${ }^{10}$ as proxy of total lipid content, TG being the principal lipid class in mollusks. ${ }^{11}$

Fluoxetine was measured in water on days 7 and 14 as published elsewhere, ${ }^{10}$ as well as fluoxetine and norfluoxetine in snails. Briefly, an easy and quick extraction similar to Quick Easy Cheap Effective Rugged Safe (QuEChERS) procedure ${ }^{12}$ in a miniature version was developed to analyze both compounds in gastropods. The procedure involves an extraction of about 10 milligrams of matrix by $500 \mu \mathrm{L}$ of a mixture of acetonitrile: water:hexane (50/20/30) and $100 \mathrm{mg}$ of citrate buffer. Recoveries were $87 \%$ for fluoxetine and $86 \%$ for norfluoxetine. Nano-LC-nano-ESI MS/MS analysis was performed with a nano Ultimate3000 (Dionex ${ }^{\circledR}$ ) coupled with a Qtrap3200 detector (AB Sciex ${ }^{\circledR}$ ). Data were processed with Analyst 1.5. The chromatographic separation was performed in two steps: first a preconcentration step on a precol-

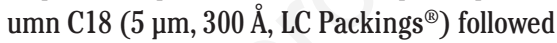
by a separation on a Pepmap C18 column (C18 $3 \mu \mathrm{m} \times 75 \mu \mathrm{m} \times 100 \AA$, Dionex $\left.{ }^{\circledR}\right)$. The column oven temperature was set to $60^{\circ} \mathrm{C}$; injection volume was $1 \mu$ Lin $\mu$ Lpickup mode; the flow rate was $300 \mathrm{~nL} / \mathrm{min}$. Samples were analyzed in positive mode with the mobile phase (A) $\mathrm{CH} 3 \mathrm{CN} / \mathrm{FA} / \mathrm{H} 2 \mathrm{O} \quad(2 / 0.1 / 97.9)$ and (B) CH3CN/FA/H2O (80/0.08/19.92), with the following elution program: start at $60 \%(\mathrm{~A})$, from 60 to $0 \%$ in $5 \mathrm{~min}$ and from 5 to $20 \mathrm{~min}, 100 \%$ (B). The column was re-equilibrated $20 \mathrm{~min}$ between runs. MS/MS detection was performed in the multiple reaction monitoring (MRM) mode using a NanoSpray ${ }^{\circledR}$ II source $\left(\mathrm{AB}\right.$ Sciex $\left.^{\circledR}\right)$. Fluoxetine and norfluoxetine were identified by their retention times, two characteristic ion transitions (fluoxetine: $310>148$ and $310>91$, norfluoxetine: $296>134$ and $296>30$ ) and specific ratios of the responses of the transitions (deviation $<20 \%$ with respect to analytical standards ratios). The quantification was carried out by double injection. The use of matrix-matched standards was selected. The matrix blank (snail) was prepared as for analysis of samples. Six-point calibration curves were built from the injection of these matrix prepared standards. This calibration intended to compensate for matrix effects. In these conditions, the limit of quantification for fluoxetine and norfluoxetine in snail samples was respectively 7.7 and $3.8 \mathrm{ng} / \mathrm{g}$.
Correspondence: Marion Gust, IRSTEA, UR MALY, Laboratoire d'écotoxicologie, 5 rue de la Doua, Villeurbanne, France.

E-mail: marion.gust@irstea.fr

Key words: fluoxetine, exposure biomarker, bioaccumulation, metabolization, gastropods.

Conference presentation: part of this paper was presented at the ECOBIM meeting, 2013 May, Montréal, Quebec, Canada.

This work is licensed under a Creative Commons Attribution NonCommercial 3.0 License (CC BYNC 3.0).

(C) Copyright M. Gust et al., 2013

Licensee PAGEPress, Italy

Journal of Xenobiotics 2013; 3(s1):e4

doi:10.4081/xeno.2013.s1.e4

Fluoxetine accumulation on days 7 and 14, was assessed by calculating bioaccumulation factor (BCF) estimates according to Nakamura et al. ${ }^{9}$ The estimate $\left(\mathrm{BCF}_{\text {tot }} \mathrm{BCF}_{\text {tot }}=\mathrm{C}_{\text {snail }} / \mathrm{C}_{\text {water }}\right)$ was calculated, using the fluoxetine concentrations measured in snails after 7 and 14 days $\left(\mathrm{C}_{\text {snail }}\right)$ for $P$. antipodarum and 7 days for $V$. piscinalis.

\section{Results and Discussion}

During the exposure, mean water temperature was $21.0 \pm 0.3^{\circ} \mathrm{C}$, mean conductivity $332 \pm 25 \mu \mathrm{S} / \mathrm{cm}$ and mean $\mathrm{pH} 7.9 \pm 0.3$. Chemical measurements showed a fluoxetine recovery in the exposure system depending on the tested concentration (from 25 to 98\%), with mean measured exposure concentrations of $2.9,24$ and $79 \mu \mathrm{g}$ fluoxetine/L (Table 1). Even if the gradient of exposure still was present, fluoxetine measured concentrations were lower than expected ones, with the lowest recovery rates for the lowest tested concentration. This is consistent with what was previously observed in similar exposure systems. ${ }^{2}$ These lower exposure concentrations can certainly be explained by adsorption on the devices used for exposure system, as fluoxetine in a relatively stable compound. ${ }^{13}$

Fluoxetine was measured in both $P$. antipodarum and $V$. piscinalis (Table 1). No significant differences $(\mathrm{P}>0.05)$ were noted between the fluoxetine concentrations in $P$. antipodarum after 7 or 14 days, suggesting that the bioaccumulation reached steady state after 7 days of exposure. In the Japanese medaka, bioaccumulation steady state was achieved after only 3 days of exposure. ${ }^{8}$ On the basis of these results which showed quick accumulation for fish and snail, we assumed that steady 
state could also be reached in $V$. piscinalis after 7 days of exposure and we compared fluoxetine body burden in the two species on day 7 . Concentrations of fluoxetine and estimate $\mathrm{BCF}_{\text {tot }}$ in $P$. antipodarum were significantly higher $(\mathrm{P}<0.05)$ than in $V$. piscinalis (Tables 1 and 2),3,8,9,14 implying a higher bioaccumulation of the parent compound in $P$. antipodarumafter 7 days of exposure. Exposure systems were rigorously similar for both species. As fluoxetine was waterborne, the contamination probably preferentially occurred across the gills. However, fluoxetine can adsorb on food as it does on sediment ${ }^{13}$ and thus oral route is not excluded and total exposure could be modified by various food consumption. Indeed, both snails have different feeding modes, $P$. antipodarum being a deposit feeder and $V$. piscinalis being a scraper. ${ }^{15}$

Many studies showed that fluoxetine concentrations were higher in lipid rich tissues, than in muscles (Table 2). Thus, it can be assumed that a difference in lipid content in both snails could also explain the differences in $\mathrm{BCF}_{\text {tot }}$ TG content in $P$. antipodarum was around seven times higher than in V. piscinalis (Figure 1), which probably explains the higher bioaccumulation of fluoxetine in the mudsnail compared to the valve snail. Therefore, the lesser sensitivity of $V$. piscinalis to waterborne fluoxetine compared to $P$. antipodarum ${ }^{2}$ could be at least partly explained by its lesser bioaccumulation in the whole body.

BCF estimates in both snails were far lower than in mussel, but higher than those calculated in fishes (Table 2). Fluoxetine bioaccumulation is strongly dependant of $\mathrm{pH},{ }^{9}$ and no data is available concerning the exposure $\mathrm{pH}$ of $E$. complanata, ${ }^{3}$ thus limiting the comparison

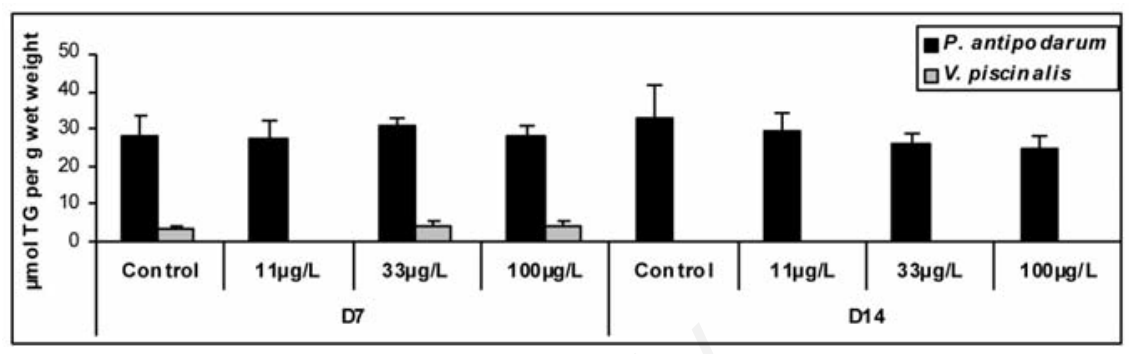

Figure 1. Levels of triglycerides in snails $\mu \mathrm{mol} / \mathrm{g}$ (mean value and standard deviation).

Table 1. Measured concentrations of fluoxetine in water $(\mu \mathrm{g} / \mathrm{L})$, snails $(\mu \mathrm{g} / \mathrm{g})$, and of norfluoxetine in snails $(\mu \mathrm{g} / \mathrm{g})$.

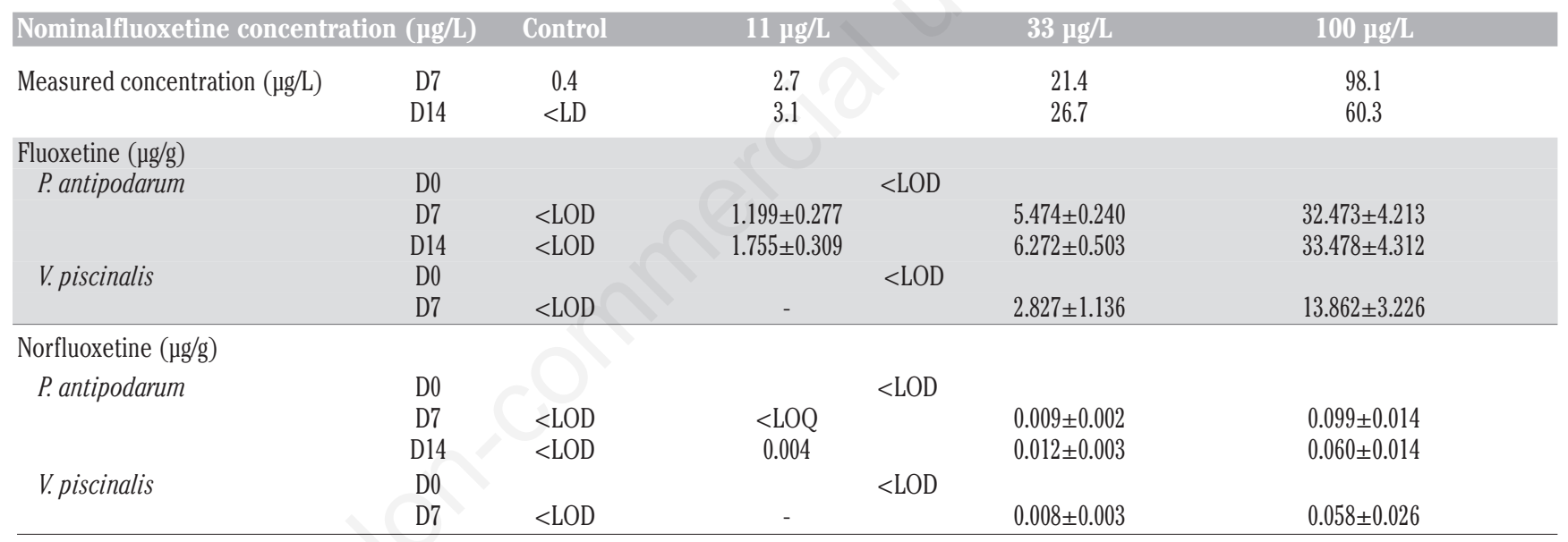

D0, D7 and D14: days 0, 7 and 14; LOD, limit of detection; LOQ, limit of quantification.

Table 2. Bioaccumulation factor (BCF) and pseudo-BCF in aquatic organisms.

\begin{tabular}{|c|c|c|c|c|c|}
\hline Species & Water concentration & Exposure duration & $\mathrm{pH}$ & Fluoxetine BCF & Norfluoxetine pseudo-BCF \\
\hline 0. latipes $^{9}$ & $10 \mu \mathrm{g} / \mathrm{L}$ & 30 days & $\begin{array}{l}7.2 \\
8.1 \\
8.9\end{array}$ & $\begin{array}{c}8.8(\mathrm{~B}), 339(\mathrm{~L}), 13(\mathrm{~B}+\mathrm{L}) \\
30(\mathrm{~B}), 580(\mathrm{~L}), 37(\mathrm{~B}+\mathrm{L}) \\
260(\mathrm{~B}), 3100(\mathrm{~L}), 330(\mathrm{~B}+\mathrm{L})\end{array}$ & $\begin{array}{l}84(\mathrm{~B}), 1500(\mathrm{~L}), 100(\mathrm{~B}+\mathrm{L}) \\
130(\mathrm{~B}), 3300(\mathrm{~L}), 170(\mathrm{~B}+\mathrm{L}) \\
650(\mathrm{~B}), 3700(\mathrm{~L}), 720(\mathrm{~B}+\mathrm{L})\end{array}$ \\
\hline 0. latipes $^{8}$ & $0.64 \mu g / L$ & 7 days & 7.4 & 74 & 117 \\
\hline O. mykiss ${ }^{16}$ & $3 \mu g / L$ & 8 days & - & 59 (M), 143 (AT) & - \\
\hline P. antipodarum & $\begin{array}{c}11 \mu \mathrm{g} / \mathrm{L} \\
33 \mu \mathrm{g} / \mathrm{L} \\
100 \mu \mathrm{g} / \mathrm{L}\end{array}$ & $7 / 14$ days & 7.9 & $\begin{array}{l}400 / 585 \\
228 / 261 \\
411 / 424 \\
\end{array}$ & $\begin{array}{l}1.3 \\
0.5 \\
0.8\end{array}$ \\
\hline V.piscinalis & $\begin{array}{c}33 \mu \mathrm{g} / \mathrm{L} \\
100 \mu \mathrm{L} / \mathrm{L}\end{array}$ & 7 days & 7.9 & $\begin{array}{l}118 \\
175\end{array}$ & $\begin{array}{l}0.3 \\
0.7\end{array}$ \\
\hline E. complanata ${ }^{3}$ & $\begin{array}{c}2.4 \mathrm{ng} / \mathrm{L} \\
7 \mathrm{ng} / \mathrm{L} \\
14 \mathrm{ng} / \mathrm{L} \\
119 \mathrm{ng} / \mathrm{L}\end{array}$ & 14 days & - & $\begin{array}{c}125 \\
1347 \\
1250 \\
665\end{array}$ & - \\
\hline
\end{tabular}

BCF, bioaccumulation factor; B, body; L, liver, B+L, body + liver; M, muscle; AT, adipose tissue. 
between species. Dietary route of exposure and lower exposure concentrations might also be in cause.

As for fluoxetine, norfluoxetine was measured in both $P$. antipodarum and $V$. piscinalis (Table 1). To our knowledge, this is the first study to investigate in vivo metabolism of a pharmaceutical in mollusk. Contrary to parental compound, norfluoxetine concentrations measured in both species were not significantly different $(\mathrm{P}>0.05)$, and norfluoxetine levels in snails represented less than $1 \%$ of total fluoxetine body burden. This suggests that $N$-demethylation is not the primary metabolite as in fish. ${ }^{16}$

Since norfluoxetine was measured in both snails, pseudo-BCFs estimates (pseudo- $\mathrm{BCF}_{\text {tot }}$ ) were calculated according to Nakamura et al., ${ }^{9}$ the denominator being the concentration of fluoxetine in water and not the concentration of norfluoxetine. Pseudo-BCF estimates (Table 2) were much lower than those determined for fluoxetine. In fishes, higher norfluoxetine concentrations in comparison to fluoxetine are measured and pseudo-BCF estimates were far higher than in gastropods (Table 2). Thus $N$ demethylation capacity is higher in fishes than in gastropods. In snails, total accumulation of fluoxetine can be reduced to fluoxetine accumulation.

The biological effects in gastropods are supported by the higher bioaccumulation of fluoxetine in the mudsnail. In humans, the norfluoxetine is more active than the parent compound, ${ }^{17}$ as in a protozoan and a crustacean 24 $\mathrm{h}$ lethality-test. ${ }^{18}$ However, the presumed active metabolite is measured in similar very low quantities in both species, implying that metabolite activation into norfluoxetine does not explain the interspecific differences previously observed. However, other metabolites cannot be excluded. Thus further studies are needed in order to better assess these issues.

\section{References}

1. Lajeunesse A, Gagnon C, Sauve S.
Determination of basic antidepressants and their n-desmethyl metabolites in raw sewage and wastewater using solid-phase extraction and liquid chromatography Tandem mass spectrometry. Anal Chem 2008;80:5325-33.

2. Gust M, Buronfosse T, Giamberini L, Ramil M, Mons R, Garric J. Effects of fluoxetine on the reproduction of two prosobranch mollusks: Potamopyrgus antipodarum and Valvata piscinalis. Environ Pollut 2009;157:423-9.

3. Bringolf RB, Heltsley RM, Newton TJ, Eads CB, Fraley SJ, Shea D, et al. Environmental occurence and reproductive effects of the pharmaceutical fluoxetine in native freshwater mussels. Environ Toxicol Chem 2010;29:1311-8.

4. Ramirez AJ, Brain RA, Usenko S, Mottaleb MA, O'Donnell JG, Stahl LL, et al. Occurrence of pharmaceuticals and personal care products in fish: results of a national pilot study in the United States. Environ Toxicol Chem 2009;28:2587-97.

5. Brooks BW, Chambliss CK, Stanley JK, Ramirez A, Banks KE, Johnson RD, et al. Determination of select antidepressants in fish from an effluent-dominated stream. Environ Toxicol Chem 2005;24:464-9.

6. Metcalfe CD, Chu SG, Judt C, Li HX, Oakes KD, Servos MR, et al. Antidepressants and their metabolites in municipal wastewater, and downstream exposure in an urban watershed. Environ Toxicol Chem 2010;29:79-89.

7. Chu S, Metcalfe CD. Analysis of paroxetine, fluoxetine and norfluoxetine in fish tissues using pressurized liquid extraction, mixed mode solid phase extraction cleanup and liquid chromatography-tandem mass spectrometry. J Chromatogr A 2007;1163:112-8.

8. Paterson G, Metcalfe CD. Uptake and depuration of the anti-depressant fluoxetine by the Japanese medaka (Oryzias latipes). Chemosphere 2008;74:125-30.

9. Nakamura Y, Yamamoto H, Sekizawa J, Kondo T, Hirai N, Tatarazako N. The effects of $\mathrm{pH}$ on fluoxetine in Japanese medaka (Oryzias latipes): Acute toxicity in fish larvae and bioaccumulation in juvenile fish. Chemosphere 2008;70:865-73.

10. Gust M, Buronfosse T, Mons R, Andre C, Gagne F, Garric J. Is exposure temperature a confounding factor for assessment of reproductive parameters of the New Zealand mudsnail Potamopyrgus antipodarum?. Aquatic Toxicol 2011;101:396-404.

11. Pazos AJ, Sánchez JL, Román G, Luz Pérez-Parallé M, Abad M. Seasonal changes in lipid classes and fatty acid composition in the digestive gland of Pecten maximus. Comp Biochem Phys B 2003;134:367-80.

12. Rouviere F, Bulete A, Cren-Olive C, Arnaudguilhem C. Multiresidue analysis of aromatic organochlorines in soil by gas chromatography-mass spectrometry and QuEChERS extraction based on water/ dichloromethane partitioning. Comparison with accelerated solvent extraction. Talanta 2012;93:336-44.

13. Kwon JW, Armbrust KL. Laboratory persistence and fate of fluoxetine in aquatic environments. Environ Toxicol Chem 2006;25: 2561-8.

14. Zhang X, Oakes KD, Cui S, Bragg L, Servos MR, Pawliszyn J. Tissue-specific in vivo bioconcentration of pharmaceuticals in rainbow trout (Oncorhynchus mykiss) Using Space-Resolved Solid-Phase Microextraction. Environ Sci Technol 2010;44:3417-22.

15. Fretter V, Graham A. British Prosobranch molluscs. Their fonctional anatomy and ecology. London: Ray Society; 1994.

16. Smith EM, Chu SG, Paterson G, Metcalfe CD, Wilson JY. Cross-species comparison of fluoxetine metabolism with fish liver microsomes. Chemosphere 2010;79:26-32.

17. Hiemke $\mathrm{C}$, Hartter S. Pharmacokinetics of selective serotonin reuptake inhibitors. Pharmacol Ther 2000;85:11-28.

18. Nalecz-Jawecki G. Evaluation of the in vitro biotransformation of fluoxetine with HPLC, mass spectrometry and ecotoxicological tests. Chemosphere 2007;70:29-35. 